\title{
Myxozoan parasites disseminated via oligochaete worms as live food for aquarium fishes: descriptions of aurantiactinomyxon and raabeia actinospore types
}

\author{
Sascha L. Hallett ${ }^{1,3}$, Stephen D. Atkinson ${ }^{1,3}$, Christer Erséus ${ }^{2,4}$, Mansour El-Matbouli ${ }^{1, *}$ \\ ${ }^{1}$ Institute of Zoology, Fish Biology and Fish Diseases, University of Munich, Kaulbachstrasse 37, 80539 Munich, Germany \\ ${ }^{2}$ Department of Invertebrate Zoology, Swedish Museum of Natural History, Box 50007, 10405 Stockholm, Sweden \\ ${ }^{3}$ Present address: Center for Fish Disease Research, Department of Microbiology, Oregon State University, Nash Hall 220, \\ Corvallis, Oregon 97331, USA \\ ${ }^{4}$ Present address: Department of Zoology, Göteborg University, Box 463, 40530 Göteborg, Sweden
}

\begin{abstract}
A total of 7 samples of live freshwater oligochaetes (mixed species), sold as 'tubifex' worms as food for aquarium fishes, were purchased over a $1 \mathrm{yr}$ period from several pet shops in Munich, Germany, and screened for parasitic infections of myxozoans. The water associated with 5 samples contained actinospores at the time of purchase; 6 samples subsequently released spores in the laboratory. In all, 12 types of actinospores (Myxozoa: Myxosporea) from 4 collective groups were released by the oligochaetes. In the current study we provide descriptions of 2 aurantiactinomyxons (Myxobolus intimus Zaika, 1965 and type 1 nov.) and 3 raabeias (type 1 and 2 nov., Raabeia type 1 of Oumouna et al., 2003); descriptions of the 5 triactinomyxon and 2 hexactinomyxon types have been published previously. We include both raabeia and echinactinomyxon types in differential diagnoses of our raabeia forms because a clear distinction between these groups no longer exists in the literature. Comparison of 18S rDNA sequence data revealed that 1 of the novel aurantiactinomyxons was Myxobolus intimus. The sale of worms hundreds of $\mathrm{km}$ away from their point of origin is a means of dissemination of myxozoan parasites.
\end{abstract}

KEY WORDS: Actinospore $\cdot$ Myxozoa $\cdot$ Oligochaete $\cdot$ Pet shop $\cdot$ Parasite dispersal

Resale or republication not permitted without written consent of the publisher

\section{INTRODUCTION}

Freshwater 'tubifex' worms (Annelida: Oligochaeta) are a common fish food sold in pet shops in a variety of forms including dried, frozen and live. Despite the name, 'tubifex' worms often comprise mixed oligochaete taxa, including lumbriculids (Lumbriculus variegatus), naids (e.g. Dero digitata) and tubificids (e.g. Tubifex tubifex, Limnodrilus hoffmeisteri and Rhyacodrilus coccineus) (Beauchamp et al. 2001). Sources of pet shop worms vary, and supplies may be transported across countries or even continents.

Oligochaetes are hosts for a number of parasites (Raftos \& Cooper 1990) and have long been known to facilitate introduction of contaminants and disease into aquaria. Shipments of 'tubifex' worms from eastern Europe to the United States have been found to be infected with myxozoan parasites (Lowers \& Bartholomew 2003) which may lead to inadvertent introduction or dissemination of these organisms. Actinospores are the myxosporean life cycle stage known to infect fish, and the ensuing myxospore development can cause disease in wild and farmed fish populations (see Kent et al. 2001).

Curious about dispersal within Europe, we purchased live 'tubifex' worms of eastern European origin from pet shops in Munich, Germany, and screened them for myxozoan infections. The survey revealed infections by 5 triactinomyxons (Hallett et al. 2004, 2005), 2 hexactinomyxons (Hallett et al. 2003), and the 2 aurantiactinomyxons and 3 raabeias described herein. 


\section{MATERIALS AND METHODS}

For detailed methodology on isolation of actinospores, identification of oligochaetes and DNA amplification, see Hallett et al. (2005).

Isolation of spores. Live 'tubifex' oligochaetes were purchased from several pet shops in Munich between March 2001 and February 2002. The water in which the oligochaetes had been kept was filtered and examined for actinospores. When spores were observed, the worm sample was sub-divided and re-examined over successive days, and finally oligochaetes were separated into multi-well plates to isolate the host.

Spores were pipetted onto a glass microscope slide under a coverslip and measured with a calibrated eyepiece micrometer. Spores were also pipetted onto glass slides and air-dried before fixing and staining with Giemsa and Diff-Quik. Spores are described herein in accordance with the guidelines of Lom et al. (1997) although we use the more popular term 'germ cell' instead of 'daughter cell'. In lieu of 'type specimen' in species descriptions, we use the term 'reference material' (Hallett et al. 2005).

Identification of host oligochaetes. Oligochaetes were processed following the protocol for marine forms by Erséus (1994) and standard keys to freshwater Oligochaeta were consulted (i.e. Kathman \& Brinkhurst 1998, Timm 1999).

Molecular analysis. To collect spores for DNA extraction, host oligochaetes were placed individually in microcentrifuge tubes in a small amount of fresh tap water for 24 to $48 \mathrm{~h}$, after which time the worm was removed and the spore sample either frozen or processed immediately. DNA was extracted using the QIAamp DNA Mini KitTissue protocol (Qiagen) according to the manufacturer's instructions, except that samples were re-suspended in $50 \mu \mathrm{l}$ distilled water.

Initial amplification of the $18 \mathrm{~S}$ small subunit ribosomal RNA gene (18S rDNA) was achieved using the primers 18e and 18g (Hillis \& Dixon 1991). Combinations of paired sequencing primers were trialled on the $18 \mathrm{e} / 18 \mathrm{~g}$ template in $20 \mu \mathrm{l}$ reactions to assess their suitability. A 5 ' end fragment of $\sim 1000$ bp in length was produced using the nested primers MYX1f and ACT1r and sequenced with those primers as well as with ACT1f and ACT1fr (Hallett \& Diamant 2001). The 3 ' end of aurantiactinomyxon was amplified with ACT3f (Hallett \& Diamant 2001) and MX3 (Andree et al. 1998) and sequenced with these primers plus ACT2f and ACT2fr (Hallett et al. 2003), whereas raabeia was amplified with ACT1f and MX3 and sequenced with these primers plus ALL1f (Hallett et al. 2002) and ACT2fr. PCR products were purified (QIAquick PCR Purification Kit, Qiagen) and sent to
Sequence Laboratories, Göttingen, Germany, for sequencing in both directions.

The various forward and reverse sequence fragments generated for each actinospore type were aligned manually in BioEdit (Hall 1999) and ambiguous bases clarified using corresponding ABI chromatograms (where a base remained indistinct, an $\mathrm{N}$ was designated). Completed sequences were submitted to GenBank and a standard nucleotide-nucleotide BLAST (blastn) search was conducted (www.ncbi.nlm. nih.gov/BLAST/; Altschul et al. 1997).

\section{RESULTS}

Over a 1 yr period, 7 samples of 'tubifex' worms from 3 Munich pet shops were screened. Worms were accompanied by a small amount of water, which in 5 cases contained actinospores at the time of purchase (Phylum Myxozoa Grassé, 1970, Class Myxosporea Bütschli, 1881) (Kent et al. 1994). Worms from 6 of the 7 samples (all 3 pet shops) released additional spores while in the laboratory. In total, 12 types of actinospores were identified: descriptions for 5 triactinomyxons and 2 hexactinomyxons have been previously published (Hallett et al. 2003, 2004, 2005); descriptions of the remaining 5 are presented here. 18S rDNA sequences were obtained from the previously undescribed aurantiactinomyxon stage of Myxobolus intimus and Raabeia type 1 of Oumouna et al., 2003.

\section{Aurantiactinomyxon stage of Myxobolus intimus Zaika, 1965}

Description. The spore possesses a spore body and 3 lateral processes (Fig. 1a-e). The spore body in apical view is circular, forms points at the sutures of valve cells, and measures $13.8 \mu \mathrm{m}$ (13.0 to $14.9 \mu \mathrm{m})$ in diameter. In side view it is ellipsoidal with a diameter of $13.6 \mu \mathrm{m}(\mathrm{n}=8)$. The polar capsules are pyriform, measuring $3.1 \times 2.3 \mu \mathrm{m}$, are prominent in side view and lie under the sutures. The extended polar filament length is $\sim 21 \mu \mathrm{m}$. Capsulogenic cells and their nuclei are prominent. Sporoplasm contains 16 germ cells, arranged in clusters of 4 (Fig. 1f, g). The processes are approximately equal, appearing finger-like to leaf-like in apical view. They are $17.7 \mu \mathrm{m}$ (15.5 to $22.0 \mu \mathrm{m})$ long, $10.7 \mu \mathrm{m}(9.7$ to $14.2 \mu \mathrm{m})$ wide near the spore body, with the largest span being $43.6 \mu \mathrm{m}$ (40.2 to $49.9 \mu \mathrm{m})$. In side view they curve downwards, are $20.1 \mu \mathrm{m}$ (18.1 to $22.0 \mu \mathrm{m}$ ) long and $10.4 \mu \mathrm{m}$ wide. The valve cell nuclei are $\sim 3 \mu \mathrm{m}$ in diameter.

Host. Limnodrilus hoffmeisteri Claparède, 1862.

Site in host. Intestinal epithelium. 

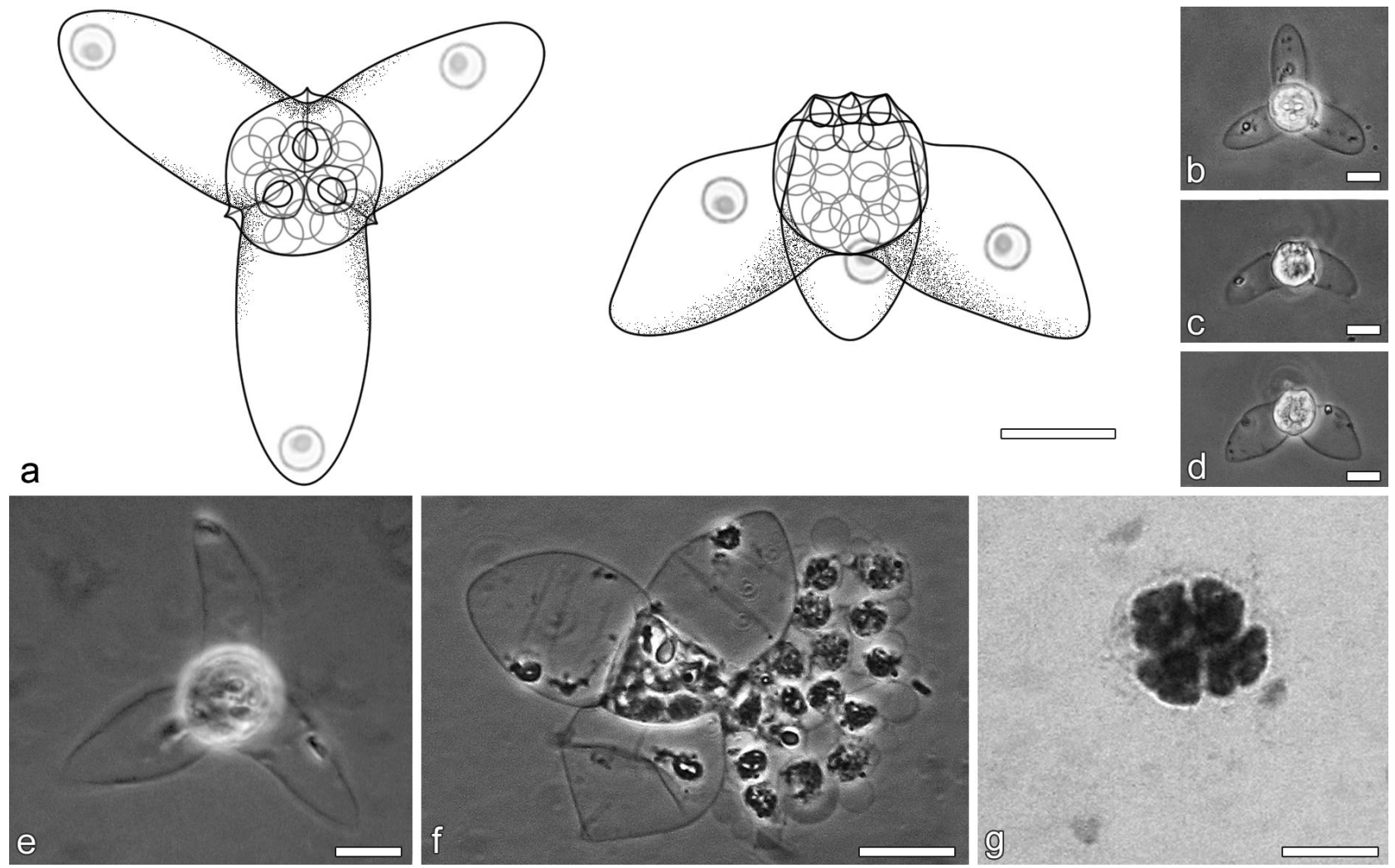

Fig. 1. Aurantiactinomyxon stage of Myxobolus intimus. (a) Line drawing of mature spore. Left, apical view; right, side view. (b-e) Fresh, unstained spores viewed at various orientations under a coverslip. (f) Severely compressed spore showing exuded sporoplasm with germ cells. (g) Stained sporoplasm with 4 clusters of 4 germ cells each. Scale bars $=10 \mu \mathrm{m}$

Source of material. Pet shop (D), Munich, Germany (purchased 22 June 2001).

Specimens deposited. Diff-Quik and Giemsa slides of air dried spores were deposited in the parasitology collection at Queensland Museum, Brisbane, Australia, accession numbers G464769 and G464770, respectively.

Remarks. We isolated 4 hosts which released this actinospore. The spore dimensions of 3 of these hosts are provided in Table 1. Spores were released for $7 \mathrm{wk}$ but not again in the following $12 \mathrm{mo}$. Spores were expelled from the worm with faeces, and tended to sink in still water.

Molecular data. $1628 \mathrm{bp}$ of $18 \mathrm{~S}$ rDNA sequence data were submitted to GenBank (AY495708).

Differential diagnosis. We compared our spore type with 34 aurantiactinomyxon types reported in the literature:
Table 1. Morphometrics (in $\mu \mathrm{m}$ ) of aurantiactinomyxon stage of Myxobolus intimus from 3 hosts $(\mathrm{A}-\mathrm{C})$ and the most similar morphotype, Aurantiactinomyxon pavinsis Marquès, 1984 (grande forme)

\begin{tabular}{|lcccc|}
\hline & Host A & Host B & Host C & A.pavinsis \\
\hline No. spores measured & 8 & 9 & 11 & \\
Apical view & & & & \\
Spore body diameter & 13.8 & 12.3 & 12.9 & 12 \\
& $(13.0-14.9)$ & $(10.4-13.0)$ & $(11.7-15.5)$ & \\
Polar capsules & $3.1 \times 2.3$ & $3.0 \times 2.7$ & $3.1 \times 2.2$ & \\
Process length & 17.7 & 16.7 & 17.7 & $15-20$ \\
& $(15.5-22.0)$ & $(14.9-18.1)$ & $(15.5-20.7)$ & \\
Width at base & 10.7 & 10.1 & 10.6 & $6-8$ \\
& $(9.7-14.2)$ & $(9.1-10.4)$ & $(8.4-13.6)$ & \\
Side view & & & & \\
Spore body diameter & 13.6 & 12.3 & 13.0 & \\
Process length & 20.1 & 19.2 & 17.5 & \\
& $(18.1-22.0)$ & $(17.5-22.0)$ & $(16.8-18.1)$ & \\
Width at base & 10.4 & 10.6 & 10.0 & \\
Largest span & 43.6 & 41.5 & 41.4 & \\
Ratio process:spore body & $(40.2-49.9)$ & $(36.3-45.3)$ & $(35.0-45.3)$ & \\
Germ cells & 16 & $1: 0.74$ & $1: 0.73$ & $1: 0.6-0.8$ \\
\hline
\end{tabular}


Marquès 1984 (4 types, one of which is Chloromyxum truttae; see Holzer et al. 2004); McGeorge et al. 1997 (1 type); Xiao \& Desser 1998b (1 type); El-Mansy et al. 1998a,b (13 types); Székely et al. 2000 (1 type); Negredo \& Mulcahy 2001 (1 type); Hallett et al. 2002 (1 type); Oumouna et al. 2003 (1 type); Özer et al. 2002 (3 types); Székely et al. 2003 (1 type). A further 7 types have been documented as part of a myxozoan life cycle: Pote et al. (2000) (Henneguya ictaluri); El-Matbouli et al. (1992) (Hoferellus carassi); Grossheider \& Körting (1992) (Hoferellus cyprini); Benajiba \& Marquès (1993) (Myxidium giardi); Székely et al. (1998) (Thelohanellus nikolskii); Lin et al. (1999) (Henneguya exilis); and Yokoyama et al. (1997) (Thelohanellus hovorkai). Comparison with the actinospore stage of Hoferellus carassi (El-Matbouli et al. 1992) or Myxidium giardi (Benajiba \& Marquès 1993) was not possible since the authors provide only a photograph with magnification but no scale bar, and no dimensions are given in the text. Nor was a comparison with Aurantiactinomyxon sp. 1 identified in Yokoyama et al. (1993) possible, for although the authors record several biological characteristics (including seasonality, longevity, circadian rhythm of spores release and chemoreception to fish mucous) they omit phenotypic details of the spores which would permit re-identification.

Initial phenotypic comparison of aurantiactinomyxons indicated closest affinity of our sample to the 'grande form' of Aurantiactinomyxon pavinsis Marquès, 1984 (Table 1); however, the host oligochaete species differed, and pairwise alignment in BioEdit of 887 bases of $18 \mathrm{~S}$ rDNA sequence revealed only $72 \%$ similarity.

Genetic data exist for 10 aurantiactinomyxons in GenBank: Aurantiactinomyxon sp. (AF378356); A. mississippiensis (AF021878); A. janiszewskai-Henneguya exilis (AF021881); Thelohanellus hovorkai (AJ133419); Aurantiactinomyxon type 1 of Negredo \& Mulcahy, 2001 (AF483598); Aurantiactinomyxon of Hallett et al., 2002 (AF487455); A. pavinsis (AJ582006); A. ictaluriH. ictaluri (AF0298320); and Aurantiactinomyxon types 1 and 3 of Özer et al., 2002 (AJ582004, AJ582005). A BLAST search showed less than $84 \%$ similarity between our aurantiactinomyxon and other sequenced aurantiactinomyxons. The search indicated a 99.9\% match with Myxobolus intimus (AY325285) with the 2 sequences differing in just 1 nucleotide. A subsequent pairwise alignment of the 2 sequences in BioEdit revealed 3 nucleotide differences over the aligned 1589 bases (99.8\% similarity) (Fig. 2).

\section{Aurantiactinomyxon type 1 nov.}

Description of reference material. The spore possesses a spore body and 3 lateral processes (Fig. $3 a-c$ ). The spore body in apical view is sub-circular with puckering at the sutures, and has a diameter of 12 (11.7 to 13.0) $\mu m_{i}$ in side view it is ellipsoidal $(n=4)$. The polar capsules $(2.3 \times 3.0 \mu \mathrm{m})$ are pyriform, are prominent in side view and lie under the sutures. The sporoplasm most likely contains 16 germ cells (Fig. 3d). The processes are approximately equal, in apical view they appear leaf-like and are 26.6 (24.6 to 31.1) $\mu \mathrm{m}$ long, 10.1 (9.1 to 10.4) $\mu \mathrm{m}$ wide at the base near the spore body; they widen in the middle 12.9 (12.3 to 13.6) $\mu \mathrm{m}$, taper almost to a point at the end with the largest span being 49.9 (44.0 to 54.4) $\mu \mathrm{m}_{\text {; }}$ in side view they curve slightly downwards. The valve cell nuclei are $\sim 2.5 \mu \mathrm{m}$ in diameter.

Host. Not isolated.

Source of material. Pet shop (D), Munich, Germany (purchased 12 August 2001).

Specimens deposited. A Giemsa-stained slide of air dried spores was deposited in the parasitology collection at Queensland Museum, Brisbane, Australia, accession number G464771.

Remarks. Spores tend to sink in still water. The oligochaete sample was sub-divided after observation of waterborne spores; however, no further spore release occurred.The host was not determined and no DNA sample was acquired.

Differential diagnosis. The spore was most similar morphometrically to the Aurantiactinomyxon of McGeorge et al., 1997 (Table 2) but the 2 differ somewhat morphologically: the processes of the latter narrow more severely than those of our type, the spore body is spherical rather than triangular/globular and the polar capsules are spherical not pyriform. Thus, our aurantiactinomyxon appears novel.
Auranti
29 tat-ctgtttgattgtcttcccattggataaccgtgggaaatctagagctaatacatgcagtt 91
M. intimus

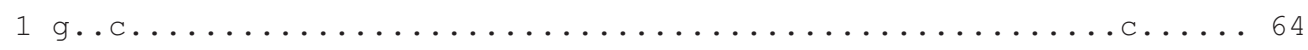

Fig. 2. Segment of the 18S rDNA sequence alignment comparing our aurantiactinomyxon (Auranti) (AY495708) and the myxospore of Myxobolus intimus (AY325285) showing position of the 3 base differences over 1589 bases. Numbers represent base position from $5^{\prime}$ end of submitted sequence 


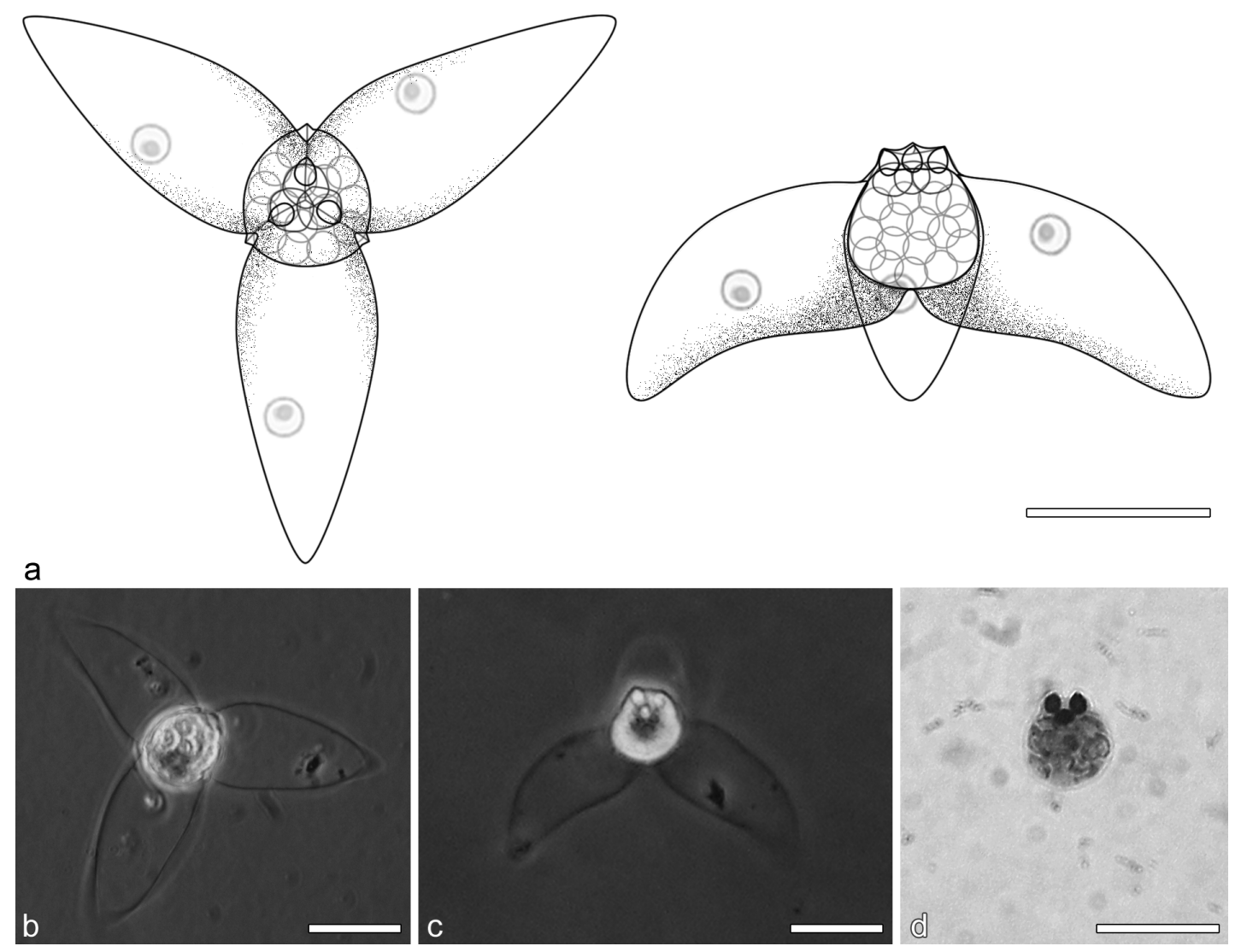

Fig. 3. Aurantiactinomyxon type 1 nov. (a) Line drawing of mature spore. Left, apical view; right, side view. (b,c) Fresh, unstained spores viewed at various orientations under a coverslip. (d) Giemsa-stained spore body highlighting the germ cells and polar capsules. Scale bars $=10 \mu \mathrm{m}$

\section{Raabeia type 1 nov.}

Description of reference material. The spore possesses a spore body and 3 caudal processes (Fig. 4a, b, Table 3). The spore body is ovate in side view, 27.2 (27.2) $\mu \mathrm{m}$ long and 16.8 (15.5 to 18.1) $\mu \mathrm{m}$ wide $(\mathrm{n}=2)$.

Table 2. Morphometrics (in $\mu \mathrm{m}$ ) of Aurantiactinomyxon type 1 nov. and most similar morphotype

\begin{tabular}{|lcc|}
\hline & $\begin{array}{c}\text { Aurantiactinomyxon } \\
\text { type 1 nov. }\end{array}$ & $\begin{array}{c}\text { Aurantiactinomyxon of } \\
\text { McGeorge et al., 1997 }\end{array}$ \\
\hline $\begin{array}{l}\text { No. spores measured } \\
\text { Spore body/spore cavity }\end{array}$ & 4 & 20 \\
$\begin{array}{l}\text { Polar capsules } \\
\text { Lateral processes }\end{array}$ & $12.0(11.7-13.0)$ & $13.7(12-15)$ \\
Length & $26.6(24.6-31.1)$ & $2.7(2-3)$ \\
Greatest width & $13.0(12.3-13.6)$ & $25.6(19-31)$ \\
Width at base & $10.1(9.1-10.4)$ & $12.0(10-14)$ \\
Largest span & $49.9(44.0-54.5)$ & \\
Ratio process:spore body & $1: 0.45$ & $1: 0.54$ \\
Germ cells & $>8(12 ?)$ & Tubifex sp. \\
Host & & \\
\hline
\end{tabular}

Polar capsules are prominent at the spore apex, are squat pyriform, directed $30^{\circ}$ outwards from the axis of the spore, are 3.9 (3.9) $\mu \mathrm{m}$ long and 3.2 (3.2) $\mu \mathrm{m}$ wide. The sporoplasm contains at least 12 germ cells (Fig. 4c). The caudal processes are approximately equal, begin two-thirds down the spore body, curve slightly outwards, then taper smoothly to a rounded point. The measurements are: length 213.2 (207.2 to 225.3) $\mu \mathrm{m}$, width at base 11.2 (10.4 to 13.0) $\mu \mathrm{m}$.

Host. Not isolated.

Source of material. Pet shop (D), Munich, Germany (purchased 8 July 2001).

Remarks. The oligochaete sample was sub-divided after observation of waterborne spores. However, no further spore release occurred; thus the host could not be segregated, and a DNA sample was not acquired.

Differential diagnosis. We compared our spore with 25 published raabeia descriptions: Janiszewska $(1955,1957)$ 


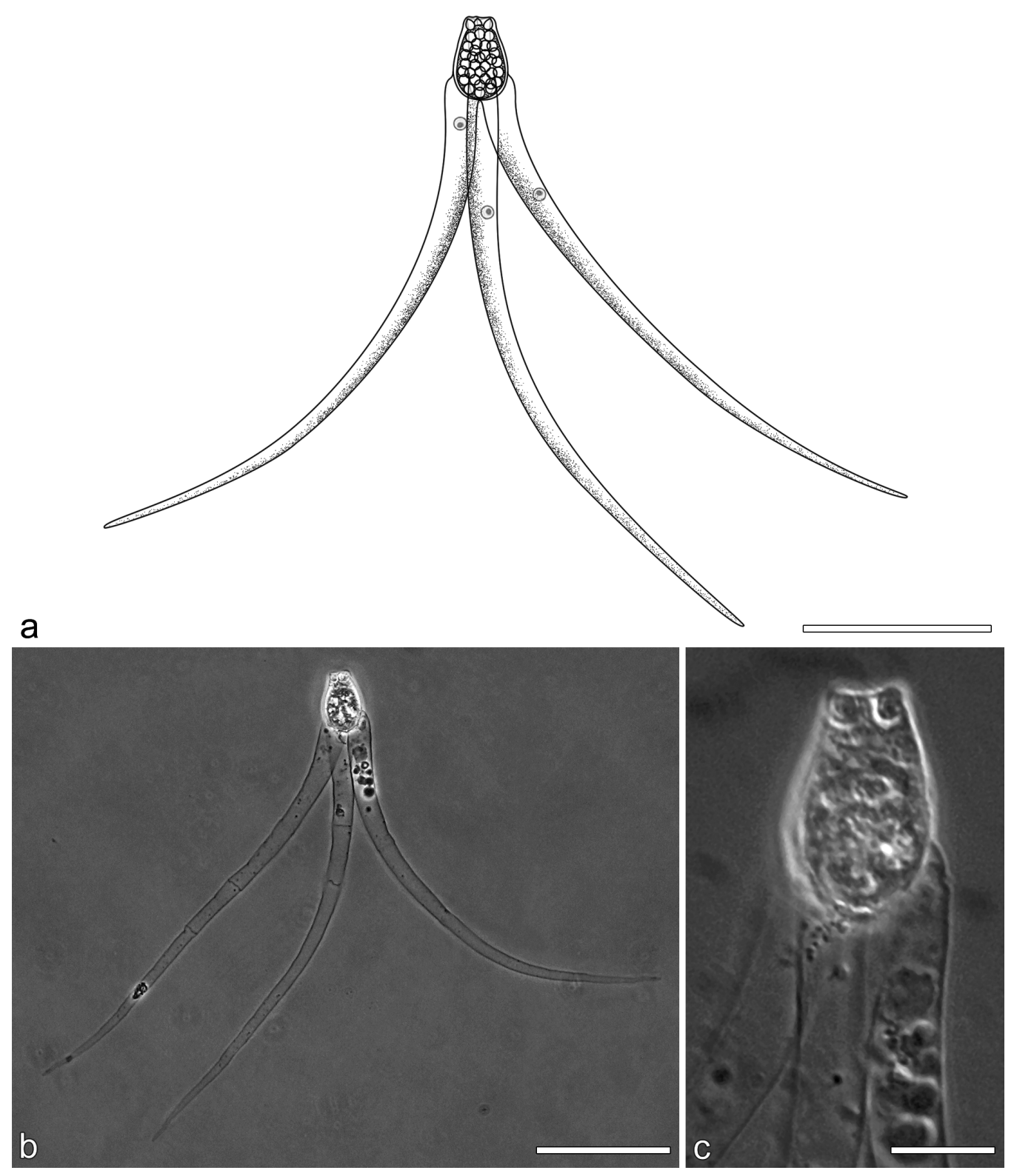

Fig. 4. Raabeia type 1 nov. (a) Line drawing of mature spore. Scale bar $=50 \mu \mathrm{m}$. (b) Fresh, unstained spore viewed under a coverslip. Scale bar $=50 \mu \mathrm{m}$ (c) Higher magnification of spore body. Scale bar $=10 \mu \mathrm{m}$

(2 types), Janiszewska \& Krzton (1973) (1 type), McGeorge et al. (1997) (1 type), Xiao \& Desser (1998a) (6 types), El-Mansy et al. (1998a,b) (4 types), Oumouna et al. (2003) (2 types), Koprivnikar \& Desser (2002) (1 type), Özer et al. 2002 (6 types, one of which is Myxidium truttae [Holzer et al. 2004]), and those whose myxospore stage is known: Yokoyama et al. 1995 (Myxobolus cultus) (note that this actinospore was also documented in Yokoyama et al. 1991, 1993) and Molnár et al. 1999 (Myxobolus dispar). Spore morphology and morphometrics of our raabeia are not consistent with any hitherto described form.

\section{Raabeia type 2 nov.}

Description of reference material. The spore possesses a spore body and 3 caudal processes (Fig. 5a,b, Table 3). Spore body, in side view sub-circular, length $22.0(22.0) \mu \mathrm{m}$, width 14.2 (13.0 to 15.5) $\mu \mathrm{m}(\mathrm{n}=2)$. The sporoplasm contains 8 germ cells each paired with a polar body (Fig. 5c). The polar capsules at the spore apex are pyriform, directed $30^{\circ}$ outwards, 4.2 (2.6 to 5.8) $\mu \mathrm{m}$ long, and 3.6 (3.2 to 3.9) $\mu \mathrm{m}$ wide. The caudal processes are approximately equal, begin two-thirds down the spore body, are relatively straight (but not 
Table 3. Morphometrics (in $\mu \mathrm{m}$ ) of raabeia spores

\begin{tabular}{|c|c|c|c|c|}
\hline & Raabeia type 1 nov. & Raabeia type 2 nov. & $\begin{array}{c}\text { Raabeia type } 1 \text { of } \\
\text { Oumouna et al., } 2003 \\
\text { (current study) }\end{array}$ & $\begin{array}{l}\text { Raabeia type } 1 \text { of } \\
\text { Oumouna et al., } 2003 \\
\text { (original description) }\end{array}$ \\
\hline No. spores & 2 & 2 & 7 & 12 \\
\hline No. germ cells & $>12$ & 8 paired with polar body & & $20-28$ \\
\hline \multicolumn{5}{|l|}{ Polar capsules } \\
\hline Length & $3.9(3.9)$ & $4.2(2.6-5.8)$ & $5.3(5.1-6.5)$ & $5 \pm 0.4$ \\
\hline Width & $3.2(3.2)$ & $3.6(3.2-3.9)$ & $3.0(2.6-3.9)$ & $3 \pm 0.2$ \\
\hline Spore body & & & & (Spore cavity) \\
\hline Length & $27.2(27.2)$ & $22.0(22.0)$ & $40.3(36.3-42.7)$ & $35 \pm 4$ \\
\hline Width & $16.8(15.5-18.1)$ & $14.2(13-15.5)$ & $10.5(9.1-11.7)$ & $12 \pm 2$ \\
\hline \multicolumn{5}{|l|}{ Process } \\
\hline Length & $213.2(207.2-225.3)$ & $120.7(114-126.9)$ & $241.8(220.2-251.6)$ & $245 \pm 13$ \\
\hline Width & $11.2(10.4-13.0)$ & $7.7(6.5-9.1)$ & $9.2(7.7-9.7)$ & \\
\hline
\end{tabular}

\section{a}
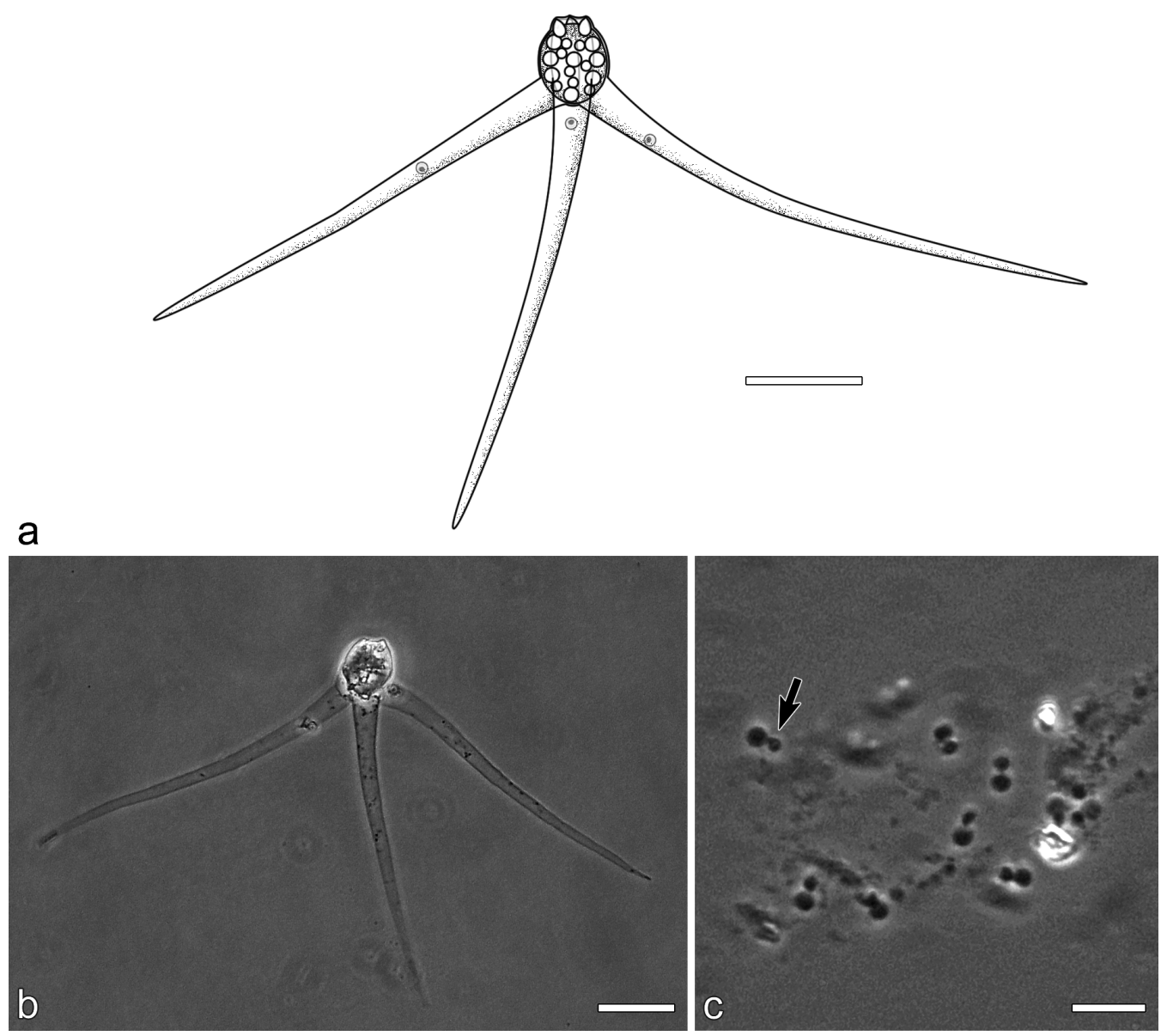

Fig. 5. Raabeia type 2 nov. (a) Line drawing of mature spore. Scale bar $=20 \mu \mathrm{m}$. (b) Fresh, unstained spore under a coverslip. Scale bar $=20 \mu \mathrm{m}$. (c) Contents of exuded sporoplasm showing the 8 germ cells each paired with a polar body (arrow). Scale bar $=10 \mu \mathrm{m}$

rigid or spine-like), taper smoothly to a point, and measure 120.7 (114.0 to 126.9$) \mu \mathrm{m}$ in length and 7.7 (6.5 to 9.1) $\mu \mathrm{m}$ in width.

Host. Not isolated.

Source of material. Pet shop (D), Munich, Germany (purchased 8 July 2001).
Remarks. The oligochaete sample was sub-divided after observation of waterborne spores. However, no further spore release occurred, the host could not be isolated and no DNA sample was acquired.

Differential diagnosis. We compared our spore both with raabeia forms and, given its resemblance to echi- 
nactinomyxons, with 13 published echinactinomyxon descriptions: Janiszewska (1957) (1 type); Marquès (1984) (1 type); Xiao \& Desser (1998b) (5 types); Negredo \& Mulcahy (2001) (2 types); Székely et al. (2002) (1 type); Özer et al. (2002) (1 type), Oumouna et al. (2003) (1 type); and 1 type whose myxospore stage is known (Sphaerospora truttae, see Özer \& Wootten 2000). Kent et al. (2001) purport that an echinactinomyxon is the alternate stage of Zschokkella sp.; however, in the original report it is ambiguous whether this myxospore alternates with an echinactinomyxon, aurantiactinomyxon or a neoactinomyxum, as the life cycle connection between these organisms was speculative (Yokoyama et al. 1991). Irrespective of this, no phenotypic information about the spores was provided.

Spore morphology and morphometrics are not consistent with any of the hitherto described raabeia or echinactinomyxon forms; they most closely identify with Echinactinomyxon 1 of Negredo \& Mulcahy, 2001 and Echinactinomyxon type 1 of Özer et al., 2002 with regard to lengths but not to widths or number of germ cells. Furthermore, neither of these types exhibits process curvature proximal to the spore body.

\section{Raabeia type 1 of Oumouna et al., 2003}

Description. The spore possesses a spore body and 3 caudal processes (Fig. 6a,b, Table 3 ). The spore body in side view is elongated oval, pinched in the middle to varying degrees, measures 40.3 (36.3 to 42.7 ) $\mu \mathrm{m}$ in length, and 10.5 (9.1 to 11.7$) \mu \mathrm{m}$ in width $(\mathrm{n}=7)$. The polar capsules are prominent at the apex with distinct nuclei and capsulogenic cells and measure 5.3 (5.1 to 6.5) $\mu \mathrm{m}$ in length, and 3.0 (2.6 to 3.9) $\mu \mathrm{m}$ in width; the extended polar filament length is 39.5 (33.7 to 45.3) $\mu \mathrm{m}$. The caudal processes are approximately equal, are curved and taper to a sharp point, are 241.8 (220.2 to 251.6$) \mu \mathrm{m}$ long, and 9.2 (7.7 to 9.7) $\mu \mathrm{m}$ wide at the base; the valve cell nuclei are clustered at the base of the spore body.

Host. Tubifex tubifex Müller, 1774.

Site in host. Not determined.

Source of material. Pet shop (D), Munich, Germany (purchased 8 August 2001).

Specimens deposited. A Diff-Quik slide of air dried spores was deposited in the parasitology collection at Queensland Museum, Brisbane, Australia, accession number G464772.

Remarks. Waterborne spores of this type were found in a second worm sample (Pet shop D, purchased 22 June 2001) but the second host worm could not be isolated. Neither squashes of fresh spores nor stained spores exhibited discrete germ cells in the sporoplasm (Fig. 6b inset, c).

Molecular data. $1640 \mathrm{bp}$ of $18 \mathrm{~S}$ rDNA sequence data were submitted to GenBank (AY495709).

Differential diagnosis. Spore morphology and morphometrics are consistent with Raabeia type 1 of Oumouna et al., 2003 and the spore is identified as such (Table 3). The 18S rDNA sequence data did not match any of the 5 raabeias in GenBank: Raabeia B of Xiao \& Desser, 1998a (AF378352); Raabeia stage of Myxobolus dispar (AF507972); Raabeia type 1 of Özer et al., 2002 (AJ582008); Raabeia type 3 of Özer et al., 2002 (AJ582009); Raabeia type 4 of Özer et al., 2002 (AJ582010). A BLAST search showed greatest similarity (96\%) with Myxidium truttae (AF201374).

\section{DISCUSSION}

The 'tubifex' samples purchased from pet shops in Munich, Germany, originated from eastern European countries and comprised at least 3 oligochaete species: Tubifex tubifex, Limnodrilus hoffmeisteri and L. udekemianus Claparède, 1862. Myxozoan infections were found in all 3 species, and some worms were releasing spores at the time of purchase. Comparison of these spores with forms in the literature indicated that the majority were novel records.

\section{Taxonomy}

Although the Class Actinosporea is suppressed and its members no longer recognised as species in their own right (pending further life cycle information) (Kent et al. 1994), it is nevertheless important that these parasites are accurately and unambiguously documented since at least some infect fish and cause disease. Actinospores are classified into collective groups (formerly genera) which appear distinct based on the original genus descriptions of spore morphology. However, as more actinospores have been encountered, it appears that, rather than fall neatly into morphological groups, they may have a continuum of form leading to some taxonomic ambiguities.

Of the spore types described herein, we found that 2 fitted clearly within the collective group Aurantiactinomyxon and 2 distinctly within Raabeia. However, a fifth spore type which we assigned as Raabeia type 2 resembled members of both Echinactinomyxon and Raabeia collective groups, and we noted from our differential diagnosis that there was no longer a clear distinction between these 2 groups in the literature. 


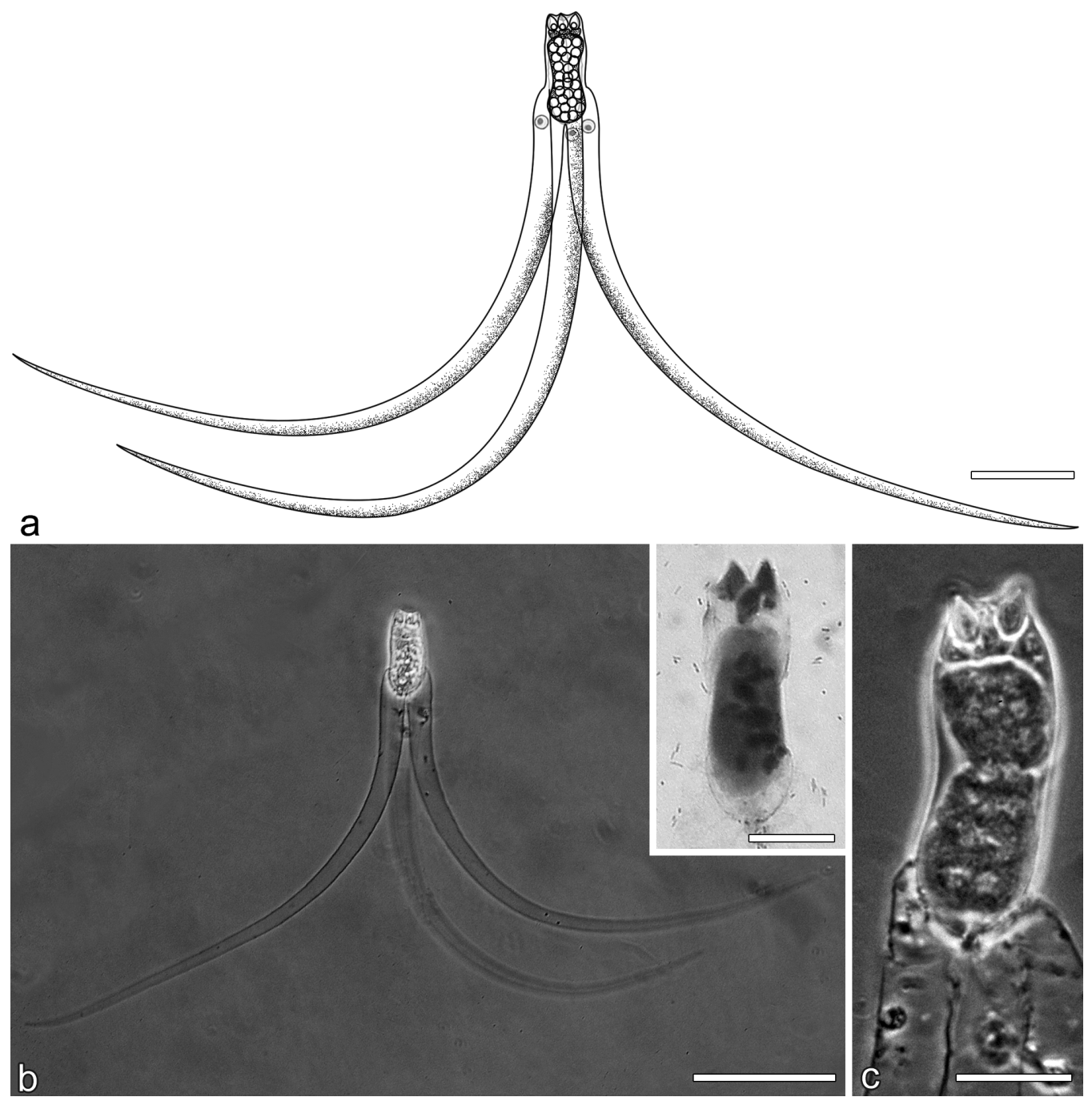

Fig. 6. Raabeia type 1 of Oumouna et al., 2003. (a) Line drawing of mature spore. Scale bar $=50$ um. (b) Fresh unstained spore viewed under a coverslip. Scale bar $=50 \mu \mathrm{m}$. Inset: Giemsa-stained spore body highlighting germ cells and polar capsules. Scale bar $=10 \mu \mathrm{m}$. (c) Higher magnification of the spore body of a second fresh spore showing 'pinching'. Scale bar $=10 \mu \mathrm{m}$

Raabeia spores are defined as: 'epispore' (now an obsolete term; Lom et al. 1997), with 3 long, pointed and curved processes arising from the epispore without a style (Janiszewska 1955). Echinactinomyxon, however, are defined by 3 equal, spiny, straight, rigid and pointed processes (Janiszewska 1957). The difficulty in assigning spores to either taxon arises when spores have shorter, slightly curved processes. We feel that the overriding echinactinomyxon characters are 'spiny, straight, rigid' processes, which our Raabeia type 2 did not possess. Its processes, however, were shorter than an architypal raabeia form and lacked a distinct deep curve. Our spore type morphologically (but not morphometrically) resembled Echinactinomyxon C of Xiao \& Desser, 1998, whose processes are straight to slightly curved, and other echinactinomyxons (see 'Differential diagnosis' in 'Results').

Janiszewska \& Krzton (1973) describe a new actinospore form with uniquely branched processes. Because the processes are also 'arched up' they assign it, appropriately, to Raabeia. Since then, several research groups have placed spores in Raabeia based on this branching characteristic, even when the spores have straight, rigid processes characteristic of echinactinomyxon forms (e.g. Molnár et al. 1999, Koprivnikar \& Desser 2002, Özer et al. 2002); this has further blurred the distinction between the 2 groups. We therefore suggest that differential diagnoses involving either raabeia or echinactinomyxon types should include members of the other collective group. 


\section{Genetic characterisation and life cycle connections}

Aurantiactinomyxon

We identified 2 spore types which we believed to be novel phenotypes. The first type was distinguished genetically from other sequenced aurantiactinomyxons, but without sequence data for our second type we could not be as definitive about its uniqueness. We were acutely aware of our previous case study (Hallett et al. 2002) in which 2 morphologically distinct aurantiactinomyxon spore types, released simultaneously from the one oligochaete, have the same 18S rDNA sequence. Although we advocate augmentation of taxonomic descriptions with molecular sequence data and consider anything else to be less than ideal, we nonetheless believe the types we encountered are worthy of record.

Comparison of $18 \mathrm{~S}$ rDNA sequences has been used to match or confirm the life cycle stages of 9 myxozoans: Myxobolus cerebralis (Andree et al. 1997), Ceratomyxa shasta (Bartholomew et al. 1997), Tetracapsuloides bryosalmonae (Anderson et al. 1999, Longshaw et al. 1999), Henneguya exilis (Lin et al. 1999), H. ictaluri (Pote et al. 2000), Ellipsomyxa gobii (Koie et al. 2004), Chloromyxum sp. (Holzer et al. 2004), C. truttae (Holzer et al. 2004) and Myxidium truttae (Holzer et al. 2004). A database search revealed a high similarity of the 18S rDNA sequence of 1 of our aurantiactinomyxons to the myxospore stage of Myxobolus intimus (AY325285), and a subsequent pairwise alignment of the 2 sequences revealed differences in only 3 base positions: a similarity of $99.8 \%$ over 1589 bases, which strongly suggests that our aurantiactinomyxon is $M$. intimus. This similarity is within the range for counterparts in the above studies (98.9 to $100 \%$ ), and is less than the level of intraspecific divergence $(<2 \%)$ observed for isolates of several myxozoans from different hosts or geographic locations (see Hallett et al. 2004).

The life cycles of 13 Myxobolus species are known and most $(85 \%)$ involve a triactinomyxon actinospore stage (see Kent et al. 2001, Székely et al. 2002). M. cultus and $M$. dispar, involve a raabeia actinospore, whereas the lifecycle of $M$. pavlovskii involves a hexactinomyxon (Kent et al. 2001). Aurantiactinomyxons have been reported as the actinospore stages of a range of myxosporean genera, including members of both Platysporina and Variisporina: Henneguya $(H$. exilis, $H$. ictaluri); Hoferellus $(H$. carassii, $H$. cyprini); Thelohanellus (T. nikolskii, T. hovorkai); Myxidium (M. giardi) (Kent et al. 2001); and Chloromyxum (C. truttae) (Holzer et al. 2004); ours is the first report of a possible myxobolus-aurantiactinomyxon combination.
Recently, the life cycle of Myxobolus intimus has been experimentally investigated (Rácz et al. 2004). In conflict with our molecular data, these authors report development of triactinomyxon spores in oligochaetes exposed to $M$. intimus myxospores from gills of roach Rutilus rutilus. However, they could not complete the life cycle and infect fish with these triactinomyxons, and also, sequence data for the triactinomyxon and myxobolus spores did not match (Cs. Székely pers. comm.). Furthermore, Tubifex tubifex was the host oligochaete of the triactinomyxons, whereas we found L. hoffmeisteri produced our aurantiactinomyxons. Myxobolus intimus is known from Hungary, one of the countries identified as a source of the pet shop worms we purchased, so it is conceivable that our worms were infected with this parasite. We feel these data, collectively, support our molecular determination that $M$. intimus alternates between a myxobolus myxospore and an aurantiactinomyxon actinospore.

Another life cycle misidentification may have occurred for Sphaerospora truttae whose myxospores were linked experimentally with an echinactinomyxon (Özer \& Wootten 2000). An echinactinomyxon later described as Echinactinomyxon type 5 by Özer et al. (2002) was identified morphologically as the Sphaerospora truttae echinactinomyxon. Subsequently, however, Holzer et al. (2004) found that Özer et al.'s (2002) Echinactinomyxon type 5 and $S$. truttae myxospores share less than $50 \%$ of their $18 \mathrm{~S}$ rDNA sequences, raising questions as to whether this echinactinomyxon was misidentifed as the earlier type shown experimentally to be $S$. truttae. Unfortunately, Özer et al. (2002) provide neither morphometrics nor an image of Echinactinomyxon type 5 (and only restate the original measurements given by Özer \& Wootten 2000). The data conflict highlights the need to either follow the complete life cycle in the laboratory (i.e. fish-worm-fish or worm-fish-worm) or confirm the putative alternate stages with molecular sequence data, and for subsequent reports of parasites to be supported by both morphological and morphometrical data.

\section{Raabeia}

Given the phenotypic similarity of our Raabeia type 2 spore to an echinactinomyxon, we conducted a literature search of both collective groups. Raabeia forms have been identified through laboratory infection experiments as species of Myxobolus, M. cultus and M. dispar (Yokoyama et al. 1995, Molnár et al. 1999), and through DNA sequence comparisons as a species of Myxidium-M. truttae (Holzer et al. 2004). A BLAST search we conducted indicated that Raabeia type 1 of Oumouna et al., 2003 identified most closely 
with M. truttae ex Oncorhynchus kisutch (AF201374), M. truttae ex Salmo trutta (AJ582061) and the Raabeia type 3 of Özer et al., 2002 (all > 96\%). Our alignment of the above 4 sequences in BioEdit and subsequent pairwise alignment of $1530 \mathrm{bp}$ revealed that Raabeia type 1 shared more bases with $M$. truttae ex $S$. trutta than M. truttae ex O. kisutch (96\% vs. $95 \%)$ and M. truttae ex S. trutta was more similar to the Raabeia type 3 of Özer et al., $2002(100 \%$; and subsequently both were identified as life cycle counterparts [Holzer et al. 2004]) than to the other M. truttae isolate (99.2\%; 12 base differences), indicating clear genetic differences between the UK and Canadian myxospore isolates. In the phylogenetic analyses conducted by Kent et al. (2001) and Holzer et al. (2004), Raabeia type B of Xiao \& Desser, 1998, also grouped with Myxidium truttae (AF201374) and a second Myxidium species. Thus, as with aurantiactinomyxon actinospores, raabeia actinospores also belong to myxosporean genera that span 2 bivalvulid suborders, Variisporina and Platysporina. Holzer et al.'s analysis also showed that Raabeia type 1 of Özer et al., 2002 clustered with Myxobolus portucalensis; in our opinion this actinospore more closely resembles an echinactinomyxon than a raabeia.

Life cycle experiments have demonstrated that echinactinomyxons belong to different myxosporean genera from those of raabeia: Sphaerospora truttae (Özer \& Wootten 2000) and Zschokkella sp. (Yokoyama et al. 1993). However, a second Zschokkella species, $Z$. nova, is a siedleckiella (Uspenkaya 1995) and a second Sphaerospora, S. renicola, is a neoactinomyxum (Grossheider \& Körting 1993). These are further examples of the inconsistent nature of which myxospore form alternates with which actinospore form.

\section{Origin and dispersal of worms}

Only 1 of the 3 Munich pet shop owners was forthcoming with details of the source of their worms: Romania and Hungary. Unlike Romania, myxozoans from Hungary have been relatively well documented. Some 34 types of actinospores are known, 13 of which are aurantiactinomyxons and 4 are raabeias (El-Mansy et al. 1998a,b). None of the types we isolated appear to be any of these. Hosts recorded by El-Mansy et al. (1998) for these types included Tubifex tubifex, Limnodrilus hoffmeisteri and a species not encountered in our samples, Branchiura sowerbyi. A similar number of myxospores are known from Hungarian fishes: ElMansy et al. $(1998 a, b)$ report on 10 species from a local lake and about 28 species from a fish farm, and a further 7 are listed in recent molecular analyses (Molnár et al. 2002, Eszterbauer 2004). Life cycles involving aurantiactinomyxon, echinactinomyxon or raabeia stages are known for at least 5 of these Myxosporea: Hoferellus carassi, H. cyprini, Thelohanellus nikolskii, T. hovorkai (all aurantiactinomyxon) (El-Matbouli et al. 1992, Grossheider \& Körting 1992, Yokoyama et al. 1997, Székely et al. 1998) and Myxobolus dispar (raabeia) (Molnar et al. 1999); 2 of the fish farm aurantiactinomyxons are the 2 Thelohanellus species (Székely et al. 1998).

Growth in the aquarium industry has lead to translocation of 100s of species of fishes and invertebrates whose survival rates have improved with expedited transportation (Carlton 1992). Some fish species are now found throughout most of the world, e.g. common carp Cyprinus carpio, common goldfish Carassius auratus, rainbow trout Oncorhynchus mykiss, and brown trout Salmo trutta (Ganzhorn et al. 1992), and hence the probability of both myxozoan hosts (vertebrate and invertebrate) being present in a novel location has also increased.

The transfer of parasites with their aquatic fish hosts is well documented: for example Myxobolus cerebralis, which is responsible for whirling disease in salmonids and remains a significant problem for farmed and wild populations of trout (Gilbert \& Granath 2003), and is a disseminated fish pathogen (Ganzhorn et al. 1992). Nine myxozoans (5 genera), including M. cerebralis, are listed in Blanc's (2001) table of major introductions and translocations of pathogens in inland European aquatic ecosystems. Yet little attention has been paid to the degree of parasite dispersal due to commercial movement (or otherwise) of their invertebrate hosts. We have reported the presence of 12 myxozoans in pet shop oligochaetes from eastern Europe sold in Germany (Hallett et al. 2003, 2004, 2005, present study), and Lowers \& Bartholomew (2003) report 7 types also from eastern Europe but sold in the United States. These findings demonstrate that both intra- and inter-continental movement of parasites with their invertebrate host facilitates widespread dispersal of these organisms.

Acknowledgements. We appreciate the support of the Alexander von Humboldt Foundation (Germany), which awarded a Research Fellowship (Munich) and a Europe Fellowship (Sweden) to S.L.H.

\section{LITERATURE CITED}

Altschul SF, Madden TL, Schäffer AA, Zhang J, Zhang Z, Miller W, Lipman DJ (1997) Gapped BLAST and PSIBLAST: a new generation of protein database search programs. Nucleic Acids Res 25:3389-3402

Anderson CL, Canning EU, Okamura B (1999) 18S rDNA sequences indicate that PKX organism parasitizes Bryozoa. Bull Eur Assoc Fish Pathol 19:194-197

Andree KB, Gresoviac SJ, Hedrick RP (1997) Small subunit ribosomal RNA sequences unite alternate actinosporean 
and myxosporean stages of Myxobolus cerebralis the causative agent of whirling disease in salmonid fish. J Eukaryot Microbiol 44:208-215

Andree KB, MacConnell E, Hedrick RP (1998) A nested polymerase chain reaction for the detection of genomic DNA of Myxobolus cerebralis in rainbow trout Oncorhynchus mykiss. Dis Aquat Org 34:145-154

Bartholomew JL, Whipple MJ, Stevens DG, Fryer JL (1997) The life cycle of Ceratomyxa shasta, a myxosporean parasite of salmonids, requires a freshwater polychaete as an alternate host. J Parasitol 83:859-868

Beauchamp KA, Kathman RD, McDowell TS, Hedrick RP (2001) Molecular phylogeny of tubificid oligochaetes with special emphasis on Tubifex tubifex (Tubificidae). Mol Phylogenet Evol 19:216-24

Benajiba MH, Marquès M (1993) The alternation of Actinomyxidian and Myxosporidian sporal forms in the development of Myxidium giardi (parasite of Anguilla anguilla) through oligochaetes. Bull Eur Assoc Fish Pathol 13:100-103

Blanc G (2001) Introduction of pathogens in European aquatic ecosystems: attempt of evaluation and realities. In: Uriarte A, Basurco B (eds) Environmental impact assessment of Mediterranean aquaculture farms. Zaragoza: CIHEAMIAMZ. Cahiers Options Méditerranéennes, Vol 55, p 37-56

Carlton JT (1992) Dispersal of living organisms into aquatic ecosystems as mediated by aquaculture and fisheries activities. In: Rosenfeld A, Mann R (eds) Dispersals of living organisms into aquatic ecosystems. Maryland Sea Grant Publications, College Park, MD, p 13-48

El-Mansy A, Székely Cs, Molnár K (1998a) Studies on the occurrence of actinosporean stages of fish myxosporeans in a fish farm of Hungary, with the description of triactinomyxon, raabeia, aurantiactinomyxon and neoactinomyxon types. Acta Vet Hung 46:259-284

El-Mansy A, Székely Cs, Molnár K (1998b) Studies on the occurrence of actinosporean stages of myxosporeans in Lake Balaton, Hungary, with the description of triactinomyxon, raabeia, and aurantiactinomyxon types. Acta Vet Hung 46:437-450

El-Matbouli M, Fischer-Scherl Th, Hoffmann RW (1992) Transmission of Hoferellus carassi Achmerov, 1960 to goldfish Carassius auratus via an aquatic oligochaete. Bull Eur Assoc Fish Pathol 12:54-56

Erséus C (1994) The Oligochaeta. In: Blake JA, Hilbig B (eds) Taxonomic atlas of the benthic fauna of the Santa Maria Basin and Western Santa Barbara Channel. Santa Barbara Museum of Natural History, Santa Barbara, CA, p 5-15

Eszterbauer E (2004) Genetic relationship among gill-infecting Myxobolus species (Myxosporea) of cyprinids: molecular evidence of importance of tissue-specificity. Dis Aquat Org 58:35-40

Ganzhorn J, Rohovec JS, Fryer JL (1992) Dissemination of microbial pathogens through introductions and transfers of finfish. In: Rosenfeld A, Mann R (eds) Dispersals of living organisms into aquatic ecosystems. Maryland Sea Grant Publications, College Park, MD, p 175-192

Gilbert MA, Granath WO Jr (2003) Whirling disease of salmonid fish: life cycle, biology, and disease. J Parasitol 89:658-667

Großheider G, Körting W (1992) First evidence that Hoferellus cyprini (Doflein, 1898) is transmitted by Nais sp. Bull Eur Assoc Fish Pathol 12:17-20

Großheider G, Körting W (1993) Experimental transmission of Sphaerospora renicola to common carp Cyprinus carpio fry. Dis Aquat Org 16:91-95

Hall TA (1999) BioEdit: a user-friendly biological sequence alignment editor and analysis program for Windows 95/98/NT. Nucleic Acids Symp Ser 41:95-98

Hallett SL, Diamant A (2001) Ultrastructure and small-subunit ribosomal DNA sequence of Henneguya lesteri n. sp. (Myxosporea), a parasite of sand whiting Sillago analis (Sillaginidae) from the coast of Queensland, Australia. Dis Aquat Org 46:197-212

Hallett SL, Atkinson SD, El-Matbouli M (2002) Molecular characterisation of 2 aurantiactinomyxon (Myxozoa) phenotypes reveals one genotype. J Fish Dis 25:627-631

Hallett SL, Atkinson SD, Schöl H, El-Matbouli M (2003) Characterisation of two novel types of hexactinomyxon spores (Myxozoa) with subsidiary protrusions on their caudal processes using scanning electron microscopy and $18 \mathrm{~S}$ rDNA sequence data. Dis Aquat Org 55:45-57

Hallett SL, Atkinson SD, Erséus C, El-Matbouli M (2004) Molecular methods clarify morphometric variation in triactinomyxon (Myxozoa) spores released from different oligochaete hosts. Syst Parasitol 57:1-14

Hallett SL, Atkinson SD, Erséus C, El-Matbouli M (2005) Dissemination of triactinomyxons (Myxozoa) via oligochaetes used as live food for aquarium fish. Dis Aquat Org 65:137-152

Hillis DM, Dixon MT (1991) Ribosomal DNA: molecular evolution and phylogenetic inference. Q Rev Biol 66:411-453

Holzer AS, Sommerville C, Wootten R (2004) Molecular relationships and phylogeny in a community of myxosporeans and actinosporeans based on their 18S rDNA sequences. Int J Parasitol 34:1099-1111

Janiszewska J (1955) Actinomyxidia. Morphology, ecology, history of investigations, systematics, development. Acta Parasitol Pol 2:405-437

Janiszewska J (1957) Actinomyxidia II. New systematics, sexual cycle, description of new genera and species. Zool Pol $8: 3-34$

Janiszewska J, Krzton M (1973) Raabeia furciligera sp. n. (Cnidosporidia, Actinomyxidia) from the body cavity of Limnodrilus hoffmeisteri Claparéde, 1862. Acta Protozool 12:165-167

Kathman RD, Brinkhurst RO (1998) Guide to the freshwater oligochaetes of North America. Aquatic Resources Center, College Grove, TN

Kent ML, Margolis L, Corliss JO (1994) The demise of a class of protists: taxonomic and nomenclatural revisions proposed for the protist phylum Myxozoa Grassé, 1970. Can J Zool 72:932-937

Kent ML, Andree KB, Bartholomew JL, El-Matbouli M and 12 others (2001) Recent advances in our knowledge of the Myxozoa. J Eukaryot Microbiol 48:395-413

Køie M, Whipps CM, Kent ML (2004) Ellipsomyxa gobii (Myxozoa: Ceratomyxidae) in the common goby Pomatoschistus microps (Teleostei: Gobiidae) uses Nereis spp. (Annelida: Polychaeta) as invertebrate hosts. Folia Parasitol 51:14-18

Koprivnikar J, Desser SS (2002) A new form of raabeia-type actinosporean (Myxozoa) from the oligochaete Uncinais uncinata. Folia Parasitol 49:89-92

Lin D, Hanson LA, Pote LM (1999) Small subunit ribosomal RNA sequence of Henneguya exilis (Class Myxosporea) identifies the actinosporean stage from an oligochaete host. J Eukaryot Microbiol 46:66-68

Lom J, McGeorge J, Feist SW, Morris D, Adams A (1997) Guidelines for the uniform characterisation of the actinosporean stages of parasites of the phylum Myxozoa. Dis Aquat Org 30:1-9

Longshaw M, Feist SW, Canning EU, Okamura B (1999) First identification of PKX in Bryozoans from the United King- 
dom - molecular evidence. Bull Eur Assoc Fish Pathol 19: $146-148$.

Lowers JM, Bartholomew JL (2003) Detection of myxozoan parasites in oligochaetes imported as food for ornamental fish. J Parasitol 89:84-91

Marquès A (1984) Contribution à la connaissance des Actinomyxidies: ultrastructure, cycle biologique, systématique. PhD thesis, Université des Sciences et Techniques du Languedoc, Montpellier

McGeorge J, Sommerville C, Wootten R (1997) Studies of actinosporean myxozoan stages parasitic in oligochaetes from the sediments of a hatchery where Atlantic salmon harbour Sphaerospora truttae infection. Dis Aquat Org 30:107-119

Molnár K, El-Mansy A, Székely Cs, Baska F (1999) Development of Myxobolus dispar (Myxosporea: Myxobolidae) in an oligochaete alternate host, Tubifex tubifex. Folia Parasitol 46:15-21

Molnár K, Eszterbauer E, Szélky C, Dán Á, Harrach B (2002) Morphological and molecular biological studies on intramuscular Myxobolus spp. of cyprinid fish. J Fish Dis 25:643-652

Negredo C, Mulcahy MF (2001) Actinosporean infections in oligochaetes in a river system in southwest Ireland with descriptions of three new forms. Dis Aquat Org 46:67-77

Oumouna M, Hallett SL, Hoffmann RW, El-Matbouli M (2003) Seasonal occurrence of actinosporeans (Myxozoa) and oligochaetes (Annelida) at a trout hatchery in Bavaria, Germany. Parasitol Res 89:170-184

Özer A, Wootten R (2000) The life cycle of Sphaerospora truttae (Myxozoa: Myxosporea) and some features of the biology of both the actinosporean and myxosporean stages. Dis Aquat Org 40:33-39

Özer A, Wootten R, Shinn AP (2002) Survey of actinosporean types (Myxozoa) belonging to seven collective groups found in a freshwater salmon farm in Northern Scotland. Folia Parasitol 49:189-210

Pote LM, Hanson LA, Shivaji R (2000) Small subunit ribosomal RNA sequences link the cause of proliferative gill disease in channel catfish to Henneguya n. sp. (Myxozoa: Myxosporea). J Aquat Anim Health 12:230-240

Rácz OZ, Székely Cs, Molnár K (2004) Intraoligochaete development of Myxobolus intimus (Myxosporea: Myxobolidae), a gill myxosporean of the roach (Rutilus rutilus). Folia Parasitol 51:199-207

Raftos DA, Cooper EL (1990) Diseases of Annelida. In: Kinne O (ed) Diseases of marine animals, Vol 3. Biologische Anstalt Helgoland, Hamburg, p 229-243

Editorial responsibility: Wolfgang Körting,

Hannover, Germany
Székely Cs, El-Mansy A, Molnár K, Baska F (1998) Development of Thelohanellus hovorkai and Thelohanellus nikolskii (Myxosporea: Myxozoa) in oligochaete alternate hosts. Fish Pathol 33:107-114

Székely Cs, Sitjà-Bobadilla A, Alvarez-Pellitero P (2000) First report on the occurrence of an actinosporean stage (Myxozoa) in oligochaetes from Spanish freshwaters. Acta Vet Hung 48:433-441

Székely Cs, Urawa S, Yokoyama H (2002) Occurrence of actinosporean stages of myxosporeans in an inflow brook of a salmon hatchery in the Mena River System, Hokkaido, Japan. Dis Aquat Org 49:153-160

Székely Cs, Yokoyama H, Urawa S, Timm T, Ogawa K (2003) Description of two new actinosporean types from a brook of Fuji Mountain, Honshu, and from Chitose River, Hokkaido, Japan. Dis Aquat Org 53:127-32

Timm T (1999) A guide to the Estonian Annelida. Teaduste Akadeemia Kirjastus, Estonian Academy Publishers, Tallinn

Uspenskaya AV (1995) Alternation of actinosporean and myxosporean phases in the life cycle of Zschokkella nova (Myxozoa). J Eukaryot Microbiol 42:665-668

Xiao C, Desser SS (1998a) Actinosporean stages of myxozoan parasites of oligochaetes from Lake Sasajewun, Algonquin Park, Ontario: new forms of triactinomyxon and raabeia. J Parasitol 84:998-1009

Xiao C, Desser SS (1998b) Actinosporean stages of Myxozoan parasites of oligochaetes from Lake Sasajewun, Algonquin Park, Ontario: new forms of echinactomyxon, neoactinomyxum, aurantiactinomyxon, guyenotia, synactinomyxon and antonactinomyxon. J Parasitol 84:1010-1019

Yokoyama H (1997) Transmission of Thelohanellus hovorkai Achmerov, 1960 (Myxosporea: Myxozoa) to common carp, Cyprinus carpio, through the alternate oligochaete host. Syst Parasitol 36:79-84

Yokoyama H, Ogawa K, Wakabayashi H (1991) A new collection method of Actinosporeans - a probable infective stage of myxosporeans to fishes - from tubificids and experimental infection of goldfish with the actinosporean, Raabeia sp. Gyobyo Kenkyu 26:133-138

Yokoyama H, Ogawa K, Wakabayashi H (1993) Some biological characteristics of actinosporeans from the oligochaete Branchiura sowerbyi. Dis Aquat Org 17:223-228

Yokoyama H, Ogawa K, Wakabayashi H (1995) Myxobolus cultus n. sp. (Myxosporea: Myxobolidae) in the goldfish Carassius auratus transformed from the actinosporean stage in the oligochaete Branchiura sowerbyi. J Parasitol 81:446-451

Submitted: March 10, 2005; Accepted: December 7, 2005 Proofs received from author(s): March 6, 2006 